症例

遊走胆囊の不完全捻転発症を契機に発見された胆囊癌の 1 例 平塚市民病院外科

$\begin{array}{llllll}\text { 森 屋 秀 } & \text { 樹 青木 明人 金井歳 雄 } \\ \text { 小 野 崇 典 鈴木 俊之 }\end{array}$

遊走胆重の不完全捻転症を契機に発見された胆黄癌の 1 例を経験したので報告する. 症例は82歳の女性。右季肋部痛と胆汁性嘔吐により発症, 超音波検查で胆豪壁の肥厚を

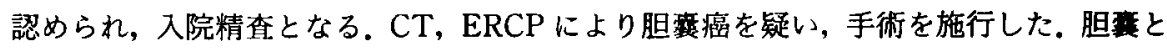
胆琝床との間に約 $3 \mathrm{~cm}$ にわたる肥厚した胆襄間膜を認め, 頸部で屈曲していた. 胆裏内 は乳頭漫潤型の胆唯癌であった。本症例の症状発現は，遊走胆毫の不完全捻転発症によ るものと考えられた。

遊走胆襄自体は病的意義は少ないが，胆蔓捻転症の基礎疾患として重要である．しか しながら，不完全捻転では，体位変換などにより捻転が容易に解除されるため，その正 確な頻度は明らかではない．上腹部不定愁訴のなかに遊走胆裹の不完全捻転に起因する ものが少なからず存在することが示唆される.

索引用語：遊走胆霍, 胆要癌, 胆蹪捻転症

はじめに

遊走胆囊は, 肝床への固定が不十分で可動性が異常 に大きい胆亯をいう”. 臨床的には，胆裏捻転症として の報告が多い。われわれは不完全捻転発症に起因する と思われる右季肋部痛と胆汁性嘔吐を契機に発見され た，胆震癌を合併した遊走胆㐮の 1 例を経験したので 報告する。

$$
\text { 症例 }
$$

患者：82歳, 女性.

主訴：右季肋部痛, 胆汁性嘔吐.

既往歴：骨粗硕症.

現病歴：92年 8 月16日右季肋部痛と胆汁性嘔吐のた め外来受診. 超音波検査にて胆䧶の著明な壁肥厚を認 め, 胆䯧癌の疑いで内科入院となる.

入院時現症：中等度龟背および軽度の春柱側䇣を認 める．発熱なし，黄疸·眇血を認めず．腹部は平坦で， 右季助部に軽度の圧痛あるも自発痛は消失していた。

入院時検査所見上, 軽度の transaminase, 胆道系醉 素の上昇および白血球增多を認めた，腫瘍マーカーは 陰性であった（表 1)。腹部超音波検査では，胆豪壁は 著しく肥厚し，内腔は狭小化していた。結石像は認め

1994年 4月13日受付 1994 年 8 月 20 日採用
表 1 入院時検查成績

\begin{tabular}{cc|lc}
\hline 末梢血 & & $\gamma \mathrm{GTP}$ & $131 \mathrm{IU} / l$ \\
$\mathrm{WBC}$ & $15,200 / \mathrm{mm}^{3}$ & LAP & $137 \mathrm{IU} / l$ \\
$\mathrm{RBC}$ & $402 \times 10^{+} / \mathrm{mm}^{3}$ & Amyl & $188 \mathrm{IU} / l$ \\
$\mathrm{Hgb}$ & $12.0 \mathrm{~g} / \mathrm{dl}$ & BUN & $12 \mathrm{mg} / \mathrm{dl}$ \\
$\mathrm{Hct}$ & $35.8 \%$ & Creat & $0.7 \mathrm{mg} / \mathrm{dl}$ \\
Plate & $21.7 \times 10^{4} / \mathrm{mm}^{3}$ & $\mathrm{Na}$ & $135 \mathrm{mEq} / l$ \\
Neutro & $87.2 \%$ & $\mathrm{~K}$ & $3.8 \mathrm{mEq} / l$ \\
Lymp & $8.1 \%$ & $\mathrm{Cl}$ & $99 \mathrm{mEq} / l$ \\
血液生化学 & & T.B. & $1.1 \mathrm{mg} / \mathrm{dl}$ \\
GOT & $144 \mathrm{IU} / l$ & T.P. & $6.0 \mathrm{~g} / \mathrm{dl}$ \\
GPT & $205 \mathrm{IU} / l$ & Alb & $3.5 \mathrm{~g} / \mathrm{dl}$ \\
LDH & $507 \mathrm{IU} / l$ & CEA & $1.3 \mathrm{ng} / \mathrm{ml}$ \\
Alp & $570 \mathrm{IU} / l$ & CA19-9 & $26 \mathrm{U} / l$ \\
\hline
\end{tabular}

なかった(図 1). 禁食, 抗生物質投与により2 日で白 血球，胆道系䣼素は正常化した，腹部 CT では，胆䨢 壁は全周性に肥厚し，壁はエンハンスされた。胆犦内 成に高吸収域をまた胆咅と肝との間に低吸収域を認め た. 胆石の存在は明らかではなかった（図 2)，ERCP では胆要は描出されず，胆裏管部の陰影欠損像を認め た。総胆管は $12 \mathrm{~mm}$ と拡張していたが，肝内胆管の拡 張は認めず，結石を認めなかった(図 3). 以上よりび まん型胆䇾腺筋症または胆犦癌を疑い，9月11日手術 を施行した。上腹部正中切開にて開腹. 開腹時, 胆莗 


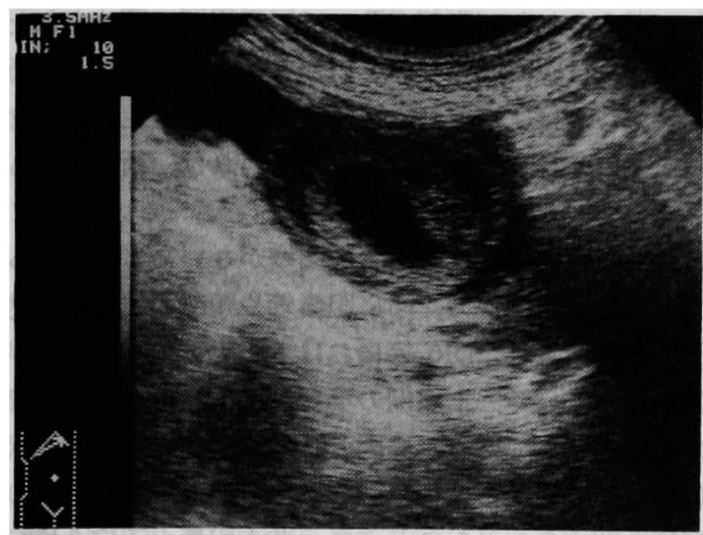

図 1 腹部超音波検査：胆暴壁の肥厚および周囲の hypo-echoic space を認める。

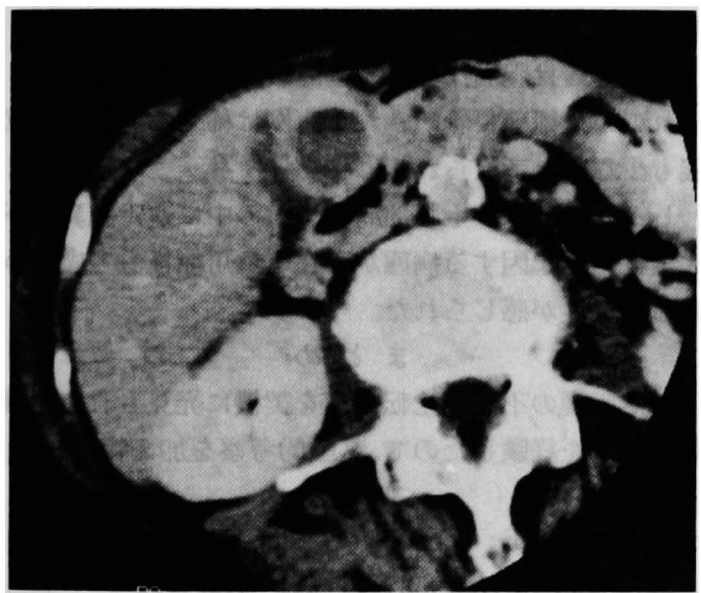

图 2 腹部 CT 検查 : enhanceされる肥厚した胆哓壁 と周囲の low density area を認める.

は頸部で軽度屈曲していた，胆輬と胆襄床との間に約 $3 \mathrm{~cm}$ におよふ肥厚した胆㟟間膜を認めた。胆裏間膜に は拡張した血管が数条走行していた(図 4). 胆亯は弾 性軟で，内胿に充満する腫煬を触知したが，漿膜面に は変化を認めなかった。肝十二指腸間膜には転移と思 われる腫大したリンパ節を触知した。胆襄間膜を含め 胆垂摘出術および肝十二指腸間膜リンパ節の一部郭清 を施行した，胆嗌内腔は乳頭状の癌でほほ充満してい たが，胆萲頸部には癌を認めなかった（図 5)。肉眼所 見は, 乳頭浸潤型で, $\mathrm{S}_{0}, \operatorname{Hinf}_{0}, \mathrm{H}_{0}, \mathrm{Binf}_{0}, \mathrm{~N}_{1}$, 組 織学的所見では, 高分化型管状腺癌で pm, INF $\beta, 1 y_{1}$, $\mathrm{v}_{0} て ゙ ， 12 \mathrm{~b} ， 12 \mathrm{c}$ リンパ節に転移を認めた。術後経過は 良好であり, 術後13日に退院した。

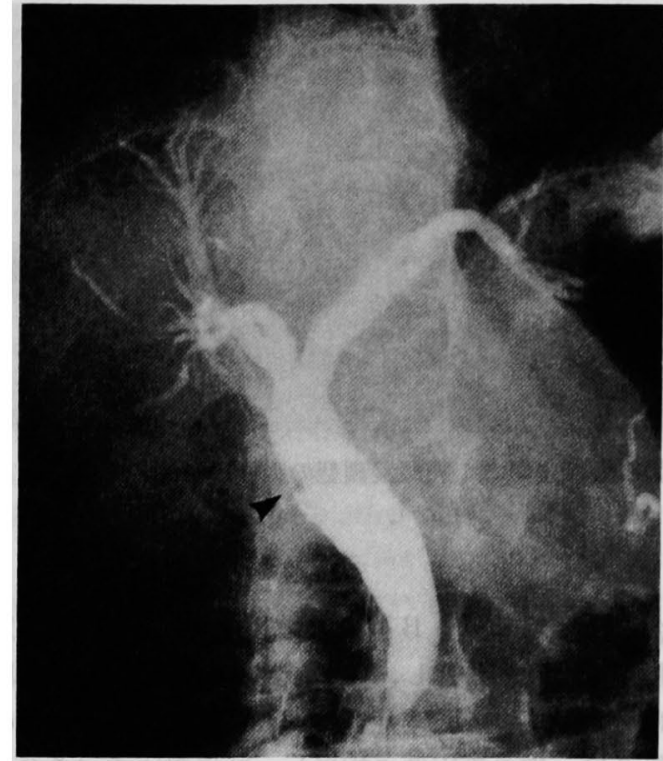

図 3 ERCP 検查：総胆管の拡張おょび胆咅管起始

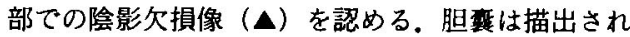
す。.

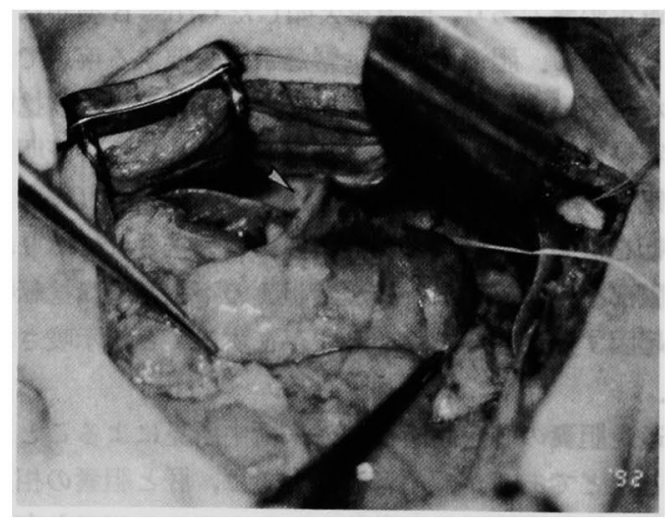

図4 術中所見：胆衰と胆襄床との間に約 $3 \mathrm{~cm}$ の胆 衰間膜（A）を認める。

\section{考 察}

遊走胆雚は, 胆裏の全体が腹膜で被覆され，その腹 膜が上面で相融合し，胆旁間膜を形成し，肝下面に眯 垂している状態である゙1. 肝との固定が不十分なため 胆襄の移動性が異常に高まり，移動性胆莗または遊走 胆䉴とよばれている。

遊走胆衰の分類として, Gross の分類", Fisher の分 類および椬の分類が有名である. Gross は胆谸および 胆亯管と肝下面との間に間膜が存在する A 型と胆豪 管のみ肝下面との間に間膜が存在し, 胆䧶体部以降は 


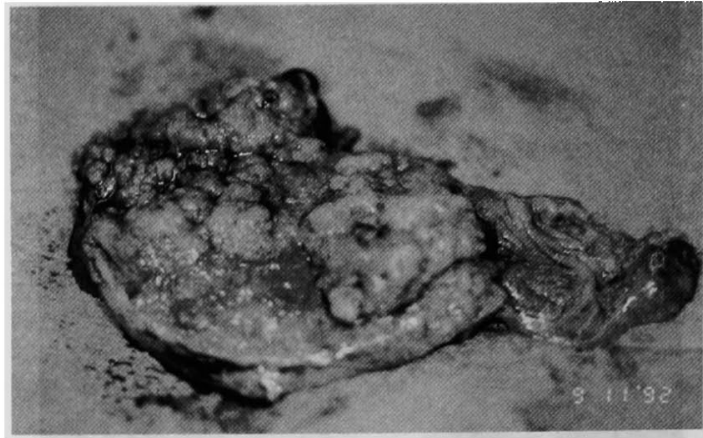

図 5 摘出標本 : 乳頭浸潤型の胆重癌を認めるが, 頸 部には及んでいない。

完全に遊離している B 型に分類した. さらに胆英固定 の程度をより細分化し, Fischer ${ }^{3)} 3$ 段階，槙は ${ }^{2)} 5$ 段 階に分類している. 本症例は Gross の A 型, Fischer の第 2 度, 槙の第IV度に相当し, 肝に着床すべき全長 にわたって肥厚した胆裏間膜を認めた。

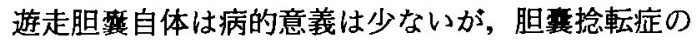
基礎疾患として重要である．胆嫨捻転症の原因の多く は遊走胆䔮であり，間膜を欠如した Gross B 型がほと んどである．胆谸捻転症は緊急手術を要する疾患であ るが, 不完全胆重捻転症では, 体位変換等により捻転 が容易に解除され，症状が消失するため，その証明は 困難であり，遊走胆衰の正確な頻度も明らかではない。 捻転を併発した症例は女性に多いと報告されており， 上腹部不定愁訴のなかに遊走胆䨢の不完全胆衰捻転症 に起因する症状が少なからず存在することが示唆され る.

遊走胆赛の確定診断は, 従来術中所見によることが ほとんどであるが，超音波検查では，肝と胆桽の相互 関係を体位変換により動的にとらえることができ有用 と考えられる。島田ら"は，遊走胆毫の超音波所見とし て，1）肝床との間につながりのない卵円形の腫瘤像, 2）胆塞壁の肥厚，3）フリーな内部エコー，4）胆豪の 正中への偏位をあげている.

本症例における一時的な右季肋部痛と胆计性煰吐 は, 遊走胆鸾の不完全捻転発症による症状発現であっ
たと考えられた。腹部 CT にて胆喜周囲に認められた 低吸収域は胆毫間膜をみていたものと考えられる。術 中所見からは，かなりの可動性があり, 遊走胆董を念 頭において超音波検查を施行していれば，術前診断も 可能であったかと思われる.

遊走胆毫の場合，胆萯管の閉塞がないにもかかわら ず, 過度の可動性のために胆重管や頸部の屈曲が頻発 すると考えられ，DIC 等における胆暴管の描出不良が 報告されている，本症例の場合，ERCPによる胆褰管 の描出が不良であった原因として, 胆集内腔が乳頭状 の癌組織で充満していた影響もあるが，胆毫管内への 浸潤を認めなかったことより，遊走胆軎の不完全捻転 に起因するものと考えられる.胆豪捻転症を起こした 遊走胆裏の報告例は数多くあるが，胆襄癌を合併した 症例は，検索しえた範囲では縄田ら5の 1 例のみであ り稀な症例と思われた。

遊走胆衰は胆妻捻転症の基礎疾患とし重要であり， それのみで術前に診断される症例は稀であり，病的意 義も少ないと考えられる.

しかしながら，上腹部痛の愁訴の中に遊走胆婁の不 完全捻転に起因する病態が存在する可能性も考慮にい れる必要性が感じられた。

\section{まとめ}

遊走胆衰の不完全捻転発症を契機に発見された胆串 癌の 1 例を経験したので, 文献的考察を加え報告した。

\section{文 献}

1) Gross RE: Congenital anomalies of the gallbladder. Arch Surg 32: 131-162, 1936

2）植 哲夫, 軽部克巳, 町田哲太他：胆塞下垂と移動 性胆蒦。臨放線 7:713-727, 1962

3) Fischer $A$ : Uber torsion der gallenblase Zentralbl Chir 52: 1527-1531, 1925

4）島田 裕, 武田克彦, 片山折夫他：胆言捻転症の臨 床的検討。日臨外医会誌 $45: 1607-1608,1984$

5）綶田純彦, 藤原敬旦, 中山富太他：胆菜癌を合併し た胆莗捻転症の 1 例。日臨外医会誌 $47: 1546$ $-1547,1986$ 


\title{
A CASE OF GALLBLADDER CARCINOMA PRESENTING WITH INCOMPLETE TORSION OF THE FLOATING GALLBLADDER
}

\author{
Hideki MORIYA, Akahito AOKI, Toshio KANAI, Takafumi ONO and Toshiyuki SUZUKI \\ Department of Surgery, Hiratsuka City Hospital
}

We experienced a resected case of adenocarcinoma in floating gallbladder. An 82-year-old woman was admitted to the hospital because of a right hypochondralgia and vomiting. Sonography demonstrated the thickened cystic wall and CT and ERCP findings were compatible with the gallbladder carcinoma. She was operated on under a diagnosis of gallbladder carcinoma. The gallbladder was evidently thickened as a tumor, and had imcomplete torsion of the mesentery of the gallbladder. The tumor was confirmed as adenocarcinoma of papillary invasion histologically. It was thought that this case manifested clinical symptoms due to imcomplete torsion of the floating gallbladder. Floating gallbladder is not morbid itself, but is important as an underlying disease of torsion of the gallbladder. Deviation of the gallbladder and an improvement in symptoms obtained by repositioning can be achieved. So actual rate of occurrence of this imcomplete torsion is obscure. It is indicated that there may be not a few patients compaining of equivocal upper abdominal symptoms, which result from imcomplete torsion of the floating gallblader. 